The Role of Discriminatory Experiences on Hispanic Students' College Choice Decisions

Amanda Taggart

Mississippi State University

Gloria Crisp

The University of Texas at San Antonio 


\begin{abstract}
This study examined the impact of discriminatory experiences on Hispanic students' decisions concerning postsecondary enrollment. Logistic regression was used to identify variables associated with Hispanic students' decisions to attend either a 2- or a 4-year institution within the context of theory concerning college choice/success. Data were drawn from a nationally representative sample $(n=2,210)$ of Hispanic students from the ELS:2002 data set. Results indicated that Hispanic students were less likely to attend a 4-year institution if they personally experienced or perceived others being discriminated against during high school. Findings suggest that discriminatory high school experiences may contribute to "tracking" Hispanic students to the community college level.
\end{abstract}

Keywords: Hispanic students, college choice, postsecondary enrollment, discriminatory experiences 


\section{The Role of Discriminatory Experiences on Hispanic Students' College Choice Decisions}

In response to the prevalence of Hispanic students attending community colleges and the gap between the bachelor's degree completion rates among non-Asian minority and White students, researchers have been engaged in work to understand the factors influencing students' college choice decisions, including whether students enroll at a 2- or a 4-year institution following high school. This line of research has been guided by econometric models (e.g., Fuller, Manski, \& Wise, 1982; Manski \& Wise, 1983) and more recently by theory concerning students' college choice decisions (e.g., Hossler \& Stage, 1992). Current findings suggest that students' choices and/or access to postsecondary education (especially for minority students) do not conform to a rational choice model driven by economic costs and benefits (Perna, 2000) but are influenced by school and parental socialization contexts (Hurtado, Inkelas, Briggs, \& ByungShik, 1997) and early school and family experiences (e.g., Paulsen \& St. John, 2002).

Researchers have examined differences in the college choice decisions of students of different ethnic groups (e.g., Perna, 2000) as well as begun work specific to Hispanic students (e.g., Arbona \& Nora, 2007; Ceja, 2006; González, Stoner, \& Jovel, 2003; O’Connor, 2009). Overall findings suggest that Hispanic parents' ability to help their children in planning for or attending college is limited (Ceja, 2006; González et al., 2003), although a rigorous academic curriculum (Arbona \& Nora, 2007; González et al., 2003) and socioeconomic status (O’Connor, 2009) influence Hispanic students' likelihood of enrolling at a 4-year institution.

A better understanding of the variables/factors associated with Hispanic students' decisions to attend a community college versus a 4-year institution is needed to guide policy and practice designed to increase access and success for Hispanic students. Although numerous variables have been identified as influencing the college enrollment decisions of Hispanic 
students, a notable gap in the literature is a lack of understanding regarding how discriminatory experiences during high school may influence students' college aspirations and eventual college choice decisions. The negative influence of discriminatory attitudes on the success of Hispanic students during college has been established within the context of college student persistence theory (e.g., Nora \& Cabrera, 1996), suggesting that discriminatory experiences may also influence student behavior/attitudes prior to college. However, no study to date has attempted to quantitatively measure the role of discriminatory experiences during high school on the enrollment decisions of Hispanic students within the context of a theoretical model that controls for variables that previously have been found to be associated with college access and success.

As such, the present study used logistic regression and a nationally representative data set to examine the demographic, academic, and sociocultural variables, discriminatory experiences, and college aspirations that affect Hispanic students' decisions to attend either a 2- or a 4-year institution. More specifically, this study attempted to (a) descriptively compare the background and high school experiences of Hispanic students who attend 4-year versus 2-year institutions and (b) understand the role of discriminatory experiences/attitudes during high school in Hispanic students' decisions to attend either a 2- or a 4-year institution.

\section{Theoretical Framework and Related Literature}

The following section offers a conceptual framework developed from relevant literature which hypothesizes that Hispanic students' interests in and decisions to eventually attend a 2- or a 4-year institution are associated with (a) demographic variables, (b) academic preparation during high school, (c) sociocultural factors, (d) discriminatory experiences both in and out of class, and (e) students' predispositions or college aspirations. As discussed in the following paragraphs, the variables in our model were drawn from college choice theory (e.g., Hossler \& 
Stage, 1992) as well as prior research specific to Hispanic students' access to college and/or academic success (e.g., Cabrera \& Nora, 1994). The model theorizes that Hispanic students' choices to attend either a 2- or a 4-year institution are shaped by numerous demographic and high school experiences, including gender, whether a student's parents were born in the United States, a student's native language, enrolling in advanced placement (AP) courses, the number of high school mathematics and English courses taken, parental education levels, participation in extracurricular activities, access to college-related information, the value friends place on higher education, parental expectations, in- and out-of-class discriminatory experiences, and a student's predisposition or aspiration to attend a 2- or a 4-year college.

Existing work has found demographic and background characteristics, including language spoken at home (Plunkett \& Bámaca-Gómez, 2003), gender (Rouse \& Austin, 2002), and generational status (Bankston \& Zhou, 2002; Rodriguez, 2002) to be related to college access and/or success for Hispanic students. Academic experiences have also been shown to influence Hispanic achievement, as measured by grades (e.g., Griffin, 2002; Hamrick, 2004; Rouse \& Austin, 2002), programs specifically designed to meet the needs of minority students (e.g., Conchas, 2001; Gibson \& Bejinez, 2002; Jodry, Robles-Piña, \& Nichter, 2004), and the level of rigor in academic courses (e.g., Arbona \& Nora, 2007; González et al., 2003; Perna, 2000). With the exception of a few studies (e.g., Goldenberg, Gallimore, Reese, \& Garnier, 2001), overall research findings to date indicate that college access and success among Hispanic students is also positively related to support and encouragement from both family (e.g., Jeynes, 2007) and friends (e.g., Newgent, Lee, \& Daniel, 2007; Sokatch, 2006). Similarly, parental influences on achievement include involvement in students' school careers, encouragement in academic endeavors, monitoring of and help with academics, educational advice, and support at 
home (e.g., Jodry et al., 2004; Martinez, 2003; Martinez, DeGarmo, \& Eddy, 2004; Rodriguez, 2002). Moreover, research has indicated that parental education levels (e.g., Plunkett \& BámacaGómez, 2003; Plunkett, Behnke, Sands, \& Choi, 2009), students' access to college-related information (Zarate \& Gallimore, 2005), and participation in extracurricular activities during high school (Faircloth \& Hamm, 2005; Flores-González, 2000; Rouse \& Austin, 2002) may also influence academic success among Hispanic students.

Finally, the items used to measure in- and out-of-class discriminatory experiences in the above mentioned theoretical framework were drawn from existing empirical work involving students' perceptions of prejudice and discrimination during college, which has indicated that minority students who perceived greater levels of discrimination at their institution are less likely to experience academic and intellectual development (Cabrera \& Nora, 1994; Cabrera, Nora, \& Castañeda, 1993; Nora \& Cabrera, 1996). In addition, our framework was informed by the work of DeGarmo and Martinez (2006), who found that discriminatory experiences may be significantly associated with lower levels of academic well-being for secondary students. However, as previously noted, no study to date has examined the impact of discriminatory experiences on Hispanic students' college choice decisions.

\section{Method}

\section{Database and Sample}

This study used data from the Education Longitudinal Study (ELS:2002). ELS:2002 tracks a nationally representative sample of students as they advance from tenth grade through high school and on to postsecondary education and/or work. As such, the study follows students as they transition through various points in their lives and educational careers to understand how earlier experiences and intentions influence later experiences. Data that were collected from the 
cohort of students sampled in ELS:2002 consist of students' tested achievement and their attitudes and experiences. These same students were again tested and surveyed in 2004 to measure their achievement gains in mathematics as well as their current school status (i.e., transfer to another school, early completion of high school, leaving school before graduation). In the latest follow-up (2006), high school completion status was again updated, and data were collected regarding students' college applications, enrollment in postsecondary education, employment, and living situations. The sample used in this study included Hispanic students who had earned a high school diploma and subsequently enrolled in postsecondary education in 2006 $\left(n=2,210^{1}\right)$.

\section{Predictor Variables}

Five blocks of variables were hypothesized to be related to Hispanic students' decisions to enroll at a 2- or a 4-year institution following high school. Four demographic variables were included in the first block of the model, including students' gender, whether one or both of the students' parents was born in the United States, and whether English was the students' native language. The role of academic preparation was measured in the second block, comprising whether the students were enrolled in AP courses during high school and the number of math and English units taken by the students in high school. Third, socio-cultural variables were added to the model: parental education levels, whether students participated in extracurricular activities, whether students accessed college-related information from a variety of sources, whether it was important to students' friends to continue education past high school, and parental expectations. The fourth set of predictor variables was then added to measure the impact of discriminatory experiences, including whether students at their schools were perceived by Hispanic students as being friendly with other racial/ethnic groups, whether racial/ethnic groups at students' schools 
often fought, whether punishment was perceived to be similar for different groups of students, and whether the Hispanic students felt put down in class by either teachers or other students. Students' predispositions or aspirations to attend a 2- or a 4-year college were included as the final block in the regression model.

\section{Outcome Variable}

As previously mentioned, the dichotomous outcome examined in the present study included whether Hispanic students enrolled in a 4-year college immediately following high school (coded as 1) versus whether they enrolled in a 2-year college (coded as 0$)$. Table 1 presents the model specifications.

[Insert Table 1 here]

\section{Data Analysis}

Descriptive statistics were computed to explore and compare the characteristics of Hispanic students who enrolled at a 2-year college versus those who chose to enroll at a 4-year institution. In addition, t tests were computed for interval or ratio level variables (such as number of mathematics courses taken) to identify significant differences among community college and 4-year enrollees. Using block sequential modeling, logistic regression was used to identify the odds of students' choosing to attend a 4-year institution, as related to the independent variables and to determine the percentage of variance in the outcome that could be explained by the predictor variables (Garson, 2008). Missing data were handled using multiple imputations (MI) with LISREL 8.80 (Enders, 2008). The variance inflation factor (VIF) was examined for each of the predictor variables as a test of multicollinearity within the model (excluding variables with a VIF greater than 2.5). Moreover, the adequacy of the logistic regression model was evaluated 
through an examination and interpretation of the overall fit of the regression model and diagnostic statistics (Peng, So, Stage, \& St. John, 2002).

\section{Results}

\section{Descriptive Findings}

A descriptive comparison of Hispanic students who attended a 4-year $(n=640)$ versus a 2-year institution $(n=1,570)$ revealed numerous differences between the two groups. Female students were slightly overrepresented at 4-year institutions (56\% vs. 49\%). Also, 4-year students were more likely to have a mother and/or father who was born in the United States. For instance, $55 \%$ of the 4 -year students had a father who was born in the United States compared with only $40 \%$ of 2 -year students. Similarly, a higher percentage of 4 -year students indicated that English was their native language (58\% vs. $45 \%$ of 2 -year students).

Some of the most striking differences between 2- and 4-year students were found in terms of academic preparation during high school. Nearly half (48\%) of Hispanic students who attended a 4-year institution had enrolled in one or more AP courses compared with a mere 9\% of students who attended a community college. Moreover, 4-year students were found to enroll in a significantly higher number of mathematics $t(1490)=-20.18, p<.001$ and English $t(1560)$ $=-9.06, p<.001$ courses during high school when compared with community college students. Over half (58\%) of the students who chose to attend a 4-year institution participated in extracurricular activities compared with only $32 \%$ of community college students. The majority of both 4-year (92\%) and 2-year (84\%) students indicated that they had access to college-related information during high school. In addition, sociocultural variables were found to be significantly related to the type of institution attended, with 4-year students having parents with significantly higher levels of education $t(1020)=-14.77, p<.001$ as well as parents with 
significantly higher expectations for their child in terms of higher education $t(1380)=-12.03, p<$ .001 when compared with Hispanic students who attended a 2-year institution. Students who chose to attend a 4-year institution were also found to have friends who placed significantly higher levels of importance on higher education $t(1340)=-10.88, p<.001$.

Significant differences were identified for four of the five discriminatory variables included in the model. More specifically, students who attended a 4-year institution were found to be significantly more likely to perceive students at their high school as being friendly with other racial groups $t(1210)=5.41, p<.001$ when compared with 2 -year students. In addition, Hispanic students who attended a 2-year institution were significantly more likely to perceive racial/ethnic fights at their school $t(1290)=-12.87, p<.001$ and to feel put down during class by teachers $t(1340)=-6.89, p<.001$ and by other students $t(1310)=-5.89, p<.001$. The final difference between Hispanic students who attended 4-year institutions compared with those who attended 2-year colleges was with regard to students' aspirations or plans to attend a 4-year institution. It is notable that of the students who enrolled at a 2-year institution, more than half $(60 \%)$ had initially aspired to attend a 4-year institution. Descriptive findings are summarized in Tables 2 and 3 .

[Insert Tables 2 and 3 here]

\section{Logistic Regression Analysis}

Table 4 displays the parameter estimates, significance values, standard errors, odds ratios, and fit statistics for the regression model. Results indicated that each block significantly improved the fit of the model, indicating that Hispanic students' decisions to attend a 4-year institution were influenced by demographic variables, academic preparation, sociocultural variables, discriminatory attitudes/experiences, and student predispositions. The overall model 
was found to be significant $\chi^{2}(20, n=2,210)=899.469, p<.001$ and yielded correct predictions for $82 \%$ of the sample. Moreover, a review of the parameter estimates and associated probabilities identified that the likelihood of choosing either a 2- or a 4-year institution was uniquely influenced by a student's native language, enrolling in AP courses and taking more mathematics classes in high school, parental education levels, participation in extracurricular activities, having access to college-related information, perceiving that racial/ethnic groups fight in school, perceiving punishment to be equitable for different students, feeling put down by other students during class, and aspirations to attend a 4-year institution.

[Insert Table 4 here]

More specifically, an examination of the direction of the odds ratios indicated that speaking English as their native language increased Hispanic students' odds of attending a 4-year institution. Concerning academic preparation, the odds of enrolling in a 4-year school were found to be 4.98 times as large for students who enrolled in AP courses during high school. Similarly, taking an additional mathematics course during high school was found to increase the odds of enrolling at a 4-year institution by a factor of 1.76. In addition, sociocultural variables, including parental education levels, participation in extracurricular activities, and access to college-related information from a variety of sources all increased the odds that Hispanic students would attend a 4-year institution. Furthermore, discriminatory experiences reported by students, such as racial/ethnic groups often fighting, punishments not being the same for all students, and often feeling put down in high school classes by other students decreased the odds of enrolling at a 4-year institution. Finally, the odds of actually attending a 4-year institution were found to be 3.34 times as large for students who aspired to or intended to enroll at a 4-year institution. 


\section{Discussion/Conclusions}

Results from this study contribute to our understanding of the variables influencing Hispanic students' decisions to enroll in either a 2- or a 4-year higher education institution. Namely, this study advances prior efforts by documenting the role of in- and out-of-class discriminatory experiences on students' college choice decisions. Descriptive findings reveal several notable differences between the background and high school experiences of students who attend 4-year versus 2-year institutions immediately following high school.

Although many of the differences (such as academic preparation) are not surprising, several findings are worthy of note. First, it is not clear whether differences in the discriminatory experiences of both groups of students are due to individual- or school-level effects. In other words, although the findings suggest that the experiences of individual students may serve to "track" students into a community college versus a 4-year institution, it is possible that this effect is actually a function of variables associated with the high school attended by the student. As such, future research should explore the possible school-level effects associated with Hispanic students' choice to attend a 2- versus a 4-year institution.

The second notable finding was the number of students who enrolled at a 2-year college immediately following high school as compared with the percentage of those same students who initially planned to attend a 4-year institution. Findings reveal that although $60 \%$ of high school students in our study who enrolled in a 2-year college reported having initial aspirations to enroll in a 4-year college, only $29 \%$ actually did so. Although at first glance it may appear that differences or weaknesses in the academic preparation of students may have served as the obstacle to attending a 4-year institution, findings of the logistic regression suggest that the discriminatory experiences of students during high school serve to decrease the odds of attending 
a 4-year institution even after controlling for academic preparation and the other variables in the model.

Another finding worthy of mention is the role of access to college information on Hispanic students' college decisions. Little variance was found in the percentage of 4- (92\%) and 2-year (84\%) students who indicated that they had access to college-related information while in high school, yet this variable was found to uniquely contribute to students' decisions to attend either a 2- or a 4-year institution (even after controlling for the other variables in the model). As such, results from this study support current policy efforts aimed at increasing access to collegerelated information for Hispanic students around the country.

Findings of the logistic regression analysis are somewhat consistent with prior research concerning the role of demographic variables on postsecondary enrollment decisions (e.g., Hossler \& Stage, 1992; Plunkett \& Bámaca-Gómez, 2003; Rouse \& Austin, 2002). Although gender and parental birthplace did not uniquely contribute to the model, the block of demographic variables was significant. Therefore, it is likely that students' gender and parents' birthplace may have been related to the decision to attend a 4-year institution but were not strong enough as the additional blocks were added to the model.

The role of academic preparation on Hispanic students' decisions to attend a 4-year institution was supported by present findings, as enrollment in AP courses and mathematics courses was found to increase students' odds of attending a 4-year institution. Results indicating that parental education levels, participation in high school extracurricular activities, and access to college-related information from a variety of sources while in high school increase the odds that Hispanic students will attend a 4-year institution are also consistent with previous research (e.g., 
Flores-González, 2000; Martinez, 2003; Martinez et al., 2004; Plunkett et al., 2009; Rouse \& Austin, 2002; Zarate \& Gallimore, 2005).

Although much of the previous research on discriminatory experiences/ attitudes focuses on students already enrolled in college (e.g., Cabrera \& Nora, 1994; Nora \& Cabrera, 1996), present findings suggest Hispanic students' discriminatory experiences during high school also may influence Hispanic students' postsecondary decisions prior to attending college. More specifically, findings of this study suggest that a racially hostile or prejudiced environment experienced by Hispanic students during high school may contribute to the "tracking" of students to the community college level, effectively limiting their odds of successfully persisting in college and/or earning a college degree. This finding is important given research findings that students who attend a community college are less likely to persist and/or earn a bachelor's degree, even after controlling for many of the variables that were also included in the present study (i.e., background variables, high school academic preparation, college aspirations; Dougherty, 1992).

It is also important to note that the data indicate that Hispanic students may be affected differently by experiences with peers, teachers, and/or school administrators, as not all of the discrimination variables were found to be significantly related to Hispanic students' college behaviors. As shown in Table 4, although items associated with discriminatory experiences with peers were found to affect Hispanic students' college behaviors, the relationship between students' college choices and experiences with teachers and/or administrators is less clear. More specifically, Hispanic students' in-class discriminatory experiences with teachers were not found to be significant in the model. At the same time, however, Hispanic students' perceptions that punishment was equally administered (presumably by teachers and/or school administrators) for 
different groups was found to be significantly related to Hispanic students' decisions to attend a 2- or a 4-year institution.

As such, additional work is needed to better understand the specific sources of discrimination (i.e., peers, teachers, administrators) that may affect Hispanic students' college going behaviors. Similarly, given the availability of variables and the quantitative nature of the present study, it is unclear exactly how these discriminatory experiences may have influenced students' decisions to enroll in either a 2- or a 4-year college. Therefore, we recommend that further research (both qualitative and quantitative) be conducted to advance scholarship on the relationship between discrimination and college choice decisions among Hispanic high school populations.

\section{Data Limitations}

A few limitations should be taken into consideration when interpreting the results. Namely, the ELS:2002 data set contains large amounts of data that are not missing at random, thereby limiting our choice of variables to include in this study. For instance, although high school grades and grade point average (e.g., Hamrick, 2004; Rouse \& Austin, 2002) have been found to influence the college decisions of Hispanic students, this variable could not be considered in the theoretical model. In addition, the ability to accurately capture the influence of sociocultural and discriminatory experiences was limited by the available variables in the ELS:2002 data set. To advance this line of research, it is recommended that researchers continue to call for and assist with the development of regionally or nationally representative longitudinal survey data that are able to quantitatively measure experiences/attitudes that have been found by qualitative researchers to influence the college decisions of Hispanic students (e.g., attending a college close to home to help take care of family members). 
Note

1. Unweighted sample sizes and degrees of freedom are rounded to the nearest ten, per IES Data Security Guidelines. 


\section{References}

Arbona, C., \& Nora, A. (2007). Predicting college attainment of Hispanic students: Individual, institutional, and environmental factors. Review of Higher Education, 30, 247-270.

Bankston, C. L., \& Zhou, M. (2002). Being well vs. doing well: Self-esteem and school performance among immigrant and nonimmigrant racial and ethnic groups. International Migration Review, 36, 389-415.

Cabrera, A. F., \& Nora, N. (1994). College students' perceptions of prejudice and discrimination and their feelings of alienation: A construct validation approach. Review of Education, 16(3-4), 387-409.

Cabrera, A. F., Nora, A., \& Castañeda, M. B. (1993). College persistence: Structural equations modeling test of an integrated model of student retention. Journal of Higher Education, 64(2), 123-139.

Ceja, M. (2006). Understanding the role of parents and siblings as information sources in the college choice process of Chicana students. Journal of College Student Development, 47(1), 87-104.

Conchas, G. Q. (2001). Structuring failure and success: Understanding the variability in Latino school engagement. Harvard Educational Review, 71, 475-504.

DeGarmo, D. S., \& Martinez, C. R. (2006). A culturally informed model of academic well-being for Latino youth: The importance of discriminatory experiences and social support. Family Relations, 55, 267-278.

Dougherty, K. J. (1992). Community colleges and baccalaureate attainment. Journal of Higher Education, 63, 188-214. 
Enders, C. K. (2008, March 25). Analysis of missing data. Paper presented at the meeting of the American Educational Research Association, New York.

Faircloth, B. S., \& Hamm, J. V. (2005). Sense of belonging among high school students representing four ethnic groups. Journal of Youth and Adolescence, 34, 293-309.

Flores-González, N. (2000). The structuring of extracurricular opportunities and Latino student retention. Journal of Poverty, 4(1/2), 85-108.

Fuller, W. C., Manski, C. F., \& Wise, D. A. (1982). New evidence on the economic determinants of postsecondary schooling choices. Journal of Human Resources, 17, 477-498.

Garson, D. (2008). Logistic Regression. Retrieved October 5, 2010, from North Carolina State University website: http://faculty.chass.ncsu.edu/garson/PA765/ logistic.htm

Gibson, M. A., \& Bejinez, L. F. (2002). Dropout prevention: How migrant education supports Mexican youth. Journal of Latinos and Education, 1, 155-175.

Goldenberg, C., Gallimore, R., Reese, L., \& Garnier, H. (2001). Cause or effect? A longitudinal study of immigrant Latino parents' aspirations and expectations, and their children's school performance. American Educational Research Journal, 38, 547-582.

González, K. P., Stoner, C., \& Jovel, J. E. (2003). Examining the role of social capital in access to college for Latinas: Toward a college opportunity framework. Journal of Hispanic Higher Education, 2, 146-170.

Griffin, B. W. (2002). Academic disidentification, race, and high school dropouts. High School Journal, 85(4), 71-81. Hamrick, F. A. (2004). College predisposition at high-minority enrollment, low-income schools. Review of Higher Education, 27, 151-168. 
Hossler, D., \& Stage, F. K. (1992). Family and high school experience influences on the postsecondary educational plans of ninth-grade students. American Educational Research Journal, 29, 425-451.

Hurtado, S., Inkelas, K. K., Briggs, C., \& Byung-Shik, R. (1997). Differences in college access and choice among racial/ethnic groups: Identifying continuing barriers. Research in Higher Education, 38(1), 43-75.

Jeynes, W. H. (2007). The relationship between parental involvement and urban secondary school student academic achievement: A meta-analysis. Urban Education, 42(1), 82-110.

Jodry, E. O., Robles-Piña, R. A., \& Nichter, M. (2004). Hispanic academic advancement theory: An ethnographic study of urban students participating in a high school advanced diploma program. High School Journal, 88, 23-31.

Manski, C. F., \& Wise, D. A. (1983). College choice in America. Cambridge, MA: Harvard University Press.

Martinez, C. R., DeGarmo, D. S., \& Eddy, J. M. (2004). Promoting academic success among Latino youths. Hispanic Journal of Behavioral Sciences, 26, 128-151.

Martinez, M. D. (2003). Missing in action: Reconstructing hope and possibility among Latino students placed at risk. Journal of Latinos and Education, 2(1), 13-21.

Newgent, R. A., Lee, S. M., \& Daniel, A. F. (2007). Interracial best friendships: Relationship with 10th graders' academic achievement level. Professional School Counseling, 11(2), 98-104.

Nora, A., \& Cabrera, A. F. (1996). The role of perceptions of prejudice and discrimination on the adjustment of minority students to college. Journal of Higher Education, 67(2), 119-148. 
O’Connor, N. (2009). Hispanic origin, socio-economic status, and community college enrollment. Journal of Higher Education, 80(2), 121-145.

Paulsen, M. B., \& St. John, E. P. (2002). Social class and college costs: Examining the financial nexus between college choice and persistence. Journal of Higher Education, 73, 189-236.

Peng, C. J., So, T. H., Stage, F. K., \& St. John, E. P. (2002). The use and interpretation of logistic regression in higher education journals: 1988-1999. Research in Higher Education, 43, 259-293.

Perna, L. W. (2000). Differences in the decision to attend college among African Americans, Hispanics, and Whites. Journal of Higher Education, 71(2), 117-141.

Plunkett, S. W., \& Bámaca-Gómez, M. Y. (2003). The relationship between parenting, acculturation, and adolescent academics in Mexican-origin immigrant families in Los Angeles. Hispanic Journal of Behavioral Sciences, 25, 222-239.

Plunkett, S. W., Behnke, A. O., Sands, T., \& Choi, B. Y. (2009). Adolescents' reports of parental engagement, and academic achievement in immigrant families. Journal of Youth and Adolescence, 38, 257-268.

Rodriguez, J. L. (2002). Family environment and achievement among three generations of Mexican American high school students. Applied Developmental Science, 6(2), 88-94.

Rouse, K. A. G., \& Austin, J. T. (2002). The relationship of gender and academic performance to motivation: Within ethnic-group variations. Urban Review, 34, 293-316.

Sokatch, A. (2006). Peer influences on the college-going decisions of low socioeconomic status urban youth. Education and Urban Society, 39, 128-146. 
Zarate, M. E., \& Gallimore, R. (2005). Gender differences in factors leading to college enrollment: A longitudinal analysis of Latina and Latino students. Harvard Educational Review, 75, 383-408. 


\section{Table 1}

Logistic Model Specifications

\begin{tabular}{l|l}
\hline Variables & \\
\hline Demographic variables & $0={\text { male }, 1=\text { female }^{a}}^{2}$ Cod \\
Gender & $0=n o, 1=$ yes $^{a}$ \\
Mother born in the United States & $0=$ no, $1=$ yes $^{a}$ \\
Father born in the United States & $0=n o, 1=$ yes $^{a}$ \\
English is student's native language &
\end{tabular}

Academic preparation

Enrolled in AP/IB courses

$0=n o, 1=y e s^{a}$

Units in mathematics

Number of units taken by student (range 0-7)

Units in English

Number of units taken by student (range 0-9.5)

Sociocultural variables

Parental education levels

8 category variable representing

highest level of parental education: $1=$ did

not complete high school, $8=$ doctoral

degree or equivalent

Participated in extracurricular (school)

$0=n o, 1=y e s^{a}$ activities

Access to college-related information from a variety of sources

$0=$ did not go to sources, $1=$ went to sources $^{\mathrm{a}}$

Important to friends to continue

$1=$ not important, 2 = somewhat

education past high school

important, 3 = very important

Parental expectations (average of mother

$1=$ less than high school, 2 = high school and father)

graduation, 3 = attend of complete 2-year, 4

= attend 4-year incomplete, 5 = bachelor's, $6=$ master's, $7=P h D$

Discriminatory experiences/attitudes 
Students friendly with other racial/ethnic $\quad 1=$ strongly agree, $4=$ strongly disagree groups

Racial/ethnic groups often fight

1 = strongly agree, 4 = strongly disagree

Punishment same no matter who you are

1 = strongly agree, 4 = strongly disagree

In class often feels put down by teachers

1 = strongly agree, 4 = strongly disagree

In class often feels put down by students

1 = strongly agree, 4 = strongly disagree

Students' predisposition (aspirations)

Type of school student plans to attend

$0=$ community college, $1=4-y e a r$ college $e^{\mathrm{a}}$

Outcome variables

Enrollment at 2- or 4-year institution $\quad 0=2$-year, $1=4$-year ${ }^{\mathrm{a}}$

Note. Unweighted sample sizes and degrees of freedom are rounded to the nearest ten, per IES Data Security Guidelines.

a. Reference category. 


\section{Table 2}

Descriptive Comparison of Students Enrolling at a 4-Year Versus 2-Year Institution

\begin{tabular}{|c|c|c|}
\hline & $\begin{array}{l}\% \text { of } 4 \text {-year students } \\
\qquad(n=640)\end{array}$ & $\begin{array}{c}\% \text { of } 2 \text {-year students } \\
(n=1,570)\end{array}$ \\
\hline \multicolumn{3}{|l|}{ Demographic variables } \\
\hline \multicolumn{3}{|l|}{ Gender } \\
\hline Male & 45 & 52 \\
\hline Female & 56 & 49 \\
\hline Mother born in the United States & 49 & 42 \\
\hline Father born in the United States & 55 & 40 \\
\hline $\begin{array}{l}\text { English is student's native } \\
\text { language }\end{array}$ & 58 & 45 \\
\hline \multicolumn{3}{|l|}{ Academic preparation } \\
\hline Enrolled in AP/IB courses & 48 & 9 \\
\hline \multicolumn{3}{|l|}{ Sociocultural variables } \\
\hline $\begin{array}{l}\text { Participated in } \\
\text { extracurricular activities }\end{array}$ & 58 & 32 \\
\hline $\begin{array}{l}\text { Access to college-related } \\
\text { information from a variety of } \\
\text { sources }\end{array}$ & 92 & 84 \\
\hline \multicolumn{3}{|l|}{$\begin{array}{l}\text { Students' predisposition } \\
\text { (aspirations) }\end{array}$} \\
\hline $\begin{array}{l}\text { Student plans to attend a } 4 \text { - } \\
\text { year institution }\end{array}$ & 92 & 60 \\
\hline
\end{tabular}


Table 3

Experiences of Students Enrolling at a 4-Year Versus 2-Year Institution

\begin{tabular}{|c|c|c|c|c|c|}
\hline & \multicolumn{2}{|c|}{$\begin{array}{l}\text { 4-year students } \\
\quad(n=640)\end{array}$} & \multicolumn{2}{|c|}{$\begin{array}{l}\text { 2-year students } \\
\quad(n=1,570)\end{array}$} & \multirow[b]{2}{*}{$t$-value } \\
\hline & M & $\mathrm{SD}$ & M & $\mathrm{SD}$ & \\
\hline \multicolumn{6}{|l|}{ Academic preparation } \\
\hline Units in mathematics & 3.58 & 0.92 & 2.65 & 1.15 & $20.18 * * *$ \\
\hline Units in English & 3.81 & 1.06 & 3.31 & 1.39 & $9.06 * * *$ \\
\hline
\end{tabular}

Sociocultural variables

$\begin{array}{llllll}\text { Parental education levels } & 3.95 & 1.99 & 2.64 & 1.64 & 14.77^{* * *} \\ \begin{array}{l}\text { Parental expectations } \\ \begin{array}{l}\text { Important to friends to continue } \\ \text { education past high school }\end{array}\end{array} & 2.43 & 1.31 & 4.65 & 1.53 & 12.03 * * * \\ & 2.68 & 0.53 & 2.40 & 0.59 & 10.88^{* * *}\end{array}$

Discriminatory experiences/attitudes

Students friendly with other racial/ethnic groups fight

Racial/ethnic groups often

Punishment same no matter who you are

In class often feels put down by teachers

In class often feels put down by students $\begin{array}{lllll}1.63 & 0.65 & 1.80 & 0.66 & 5.41 * * *\end{array}$

$\begin{array}{lllll}3.12 & 0.81 & 2.61 & 0.88 & 12.87 * * *\end{array}$

2.22

0.87

2.21

0.85

0.28

3.23

0.65

3.01

0.74

$6.89 * * *$

3.20

0.67

3.00

0.74

$5.89 * * *$ ${ }^{*} p<.05 .{ }^{*} p<.01 . * * * p<.001$. 


\section{Table 4}

Logistic Regression Model: Parameter Estimates and Model Evaluation Predicting Students' Decisions to Attend a 4-Year Versus 2-Year Institution

\begin{tabular}{|c|c|c|c|}
\hline & $b$ & SE & Odds ratio $^{\mathrm{a}}$ \\
\hline \multicolumn{4}{|l|}{ Demographic variables } \\
\hline Gender & 0.098 & .124 & \\
\hline Mother born in the United States & -0.087 & .181 & \\
\hline Father born in the United States & -0.216 & .178 & \\
\hline English is student's native language & $0.558 * * *$ & .168 & 1.748 \\
\hline \multicolumn{4}{|l|}{ Academic preparation } \\
\hline Enrolled in AP/IB courses & $1.605 * * *$ & .141 & 4.979 \\
\hline Units in mathematics & $0.566^{* * *}$ & .068 & 1.762 \\
\hline Units in English & 0.019 & .058 & \\
\hline
\end{tabular}

Sociocultural variables

Parental education levels

$\begin{array}{ll}0.215^{* * *} & .03 \\ 0.554 * * * & .122\end{array}$

Access to college-related

$0.512 *$

.202

1.240

Participated in extracurricular

034

1.739

information from a variety of sources

Important to friends to continue

0.112

.116

education past high school

Parental expectations (average of mother and father)

0.017

.046

Discriminatory experiences/attitudes

Students friendly with other

.096

racial/ethnic groups

Racial/ethnic groups often fight

$0.463 * * *$

.075

1.589

Punishment same no matter who

$0.171 *$

.074

1.186 
you are

In class often feels put down by

0.163

.099 teachers

In class often feels put down by

$0.240 *$

.095

1.271 students

Students' predisposition (aspirations)

Type of school student plans to attend

Model evaluation

$-2 \log$ likelihood

1765.105

Nagelkerke $R^{2}$

Predicted Probabilities (PCP)

$81.8 \%$

a.Odds ratios only presented for significant variables.

$* p<.05$. ** $p<.01$. *** $p<.001$. 